Article

\title{
Cost-Benefit Analysis for Energy Management in Public Buildings: Four Italian Case Studies
}

\author{
Davide Astiaso Garcia ${ }^{1, *,+}$, Fabrizio Cumo ${ }^{2,+}$, Mariagrazia Tiberi ${ }^{1,+}$, Valentina Sforzini ${ }^{1,+}$ \\ and Giuseppe Piras ${ }^{1, \dagger}$ \\ 1 DIAEE-Department of Astronautic, Electric and Energetic Engineering, Sapienza University, \\ Corso Vittorio Emanuele II 244, 00186 Rome, Italy; mariagrazia.tiberi@uniroma1.it (M.T.); \\ vale.sforzini@hotmail.it (V.S.); giuseppe.piras@uniroma1.it (G.P.) \\ 2 CITERA-Interdisciplinary Centre for Housing, Heritage and Environment, Sapienza University, \\ Via Gramsci 53, 00197 Rome, Italy; fabrizio.cumo@uniroma1.it \\ * Correspondence: davide.astiasogarcia@uniroma1.it; Tel.: +39-349-2303-498 \\ + These authors contributed equally to this work.
}

Academic Editor: Mashrur (Ronnie) Chowdhury

Received: 27 January 2016; Accepted: 4 July 2016; Published: 8 July 2016

\begin{abstract}
Improving energy efficiency in public buildings is one of the main challenges for a sustainable requalification of energy issues and a consequent reduction of greenhouse gas (GHG) emissions. This paper aims to provide preliminary information about economic costs and energy consumption reductions (benefits) of some considered interventions in existing public buildings. Methods include an analysis of some feasible interventions in four selected public buildings. Energy efficiency improvements have been assessed for each feasible intervention. The difference of the building global energy performance index $\left(E P_{\text {gl }}\right)$ has been assessed before and after each intervention. Economic costs of each intervention have been estimated by averaging the amount demanded by different companies for the same intervention. Results obtained show economic costs and the $E P_{\mathrm{gl}}$ percentage improvement for each intervention, highlighting and allowing for the comparison of energy consumption reduction and relative economic costs. The research results come from data gathered from four public buildings, and as such they could not be used to generically identify cost-beneficial energy efficiency interventions for every context or building type. However, the data reveals useful cost based considerations for selecting energy efficiency interventions in other public buildings.
\end{abstract}

Keywords: cost-benefit analysis; energy efficiency; public buildings; trigeneration plant; thermostatic valves; geothermal plant; building envelope; retrofitting; energy demand savings

\section{Introduction}

Energy efficiency assessment is an evaluation process to promote the improvement of building energy performance starting from the information gathered during specific surveys or provided by owners and users about energy consumption required to maintain a specified indoor climate in terms of temperature and relative humidity [1]. Improving energy efficiency is considered one of the main strategies nationally and internationally for reducing greenhouse gas (GHG) emissions with acceptable economic costs [1]. Energy consumption in the building sector and the subsequent impacts mainly in terms of GHG and other pollutant emissions on the atmosphere are widely discussed [2]. Moreover, the need to provide simple and clear methods to people and business operators about strategies and methods for improving energy efficiency is pointed out in many studies [1]. In order to decrease building energy consumption, almost all governments have released for their countries specific regulations aimed at improving building energy efficiency. In Europe, many national rules 
come from the European Union (EU) Directive about 2020 targets, the so-called climate package, for reducing GHG emissions, that include the $20 \%$ of renewable energy sources (RES) in energy consumption and the 20\% increase in energy efficiency (Directive 2009/29/EC) [2]; moreover energy efficiency is one of the main pillars of smart cities $[3,4]$. At the local level, an important role is played by single municipalities that in Italy deal with the implementation of the Building Energy Regulation Codes (BERC) [2]. These codes help to reduce the environmental impacts of new or refurbished buildings; their use directly affects the work of all the actors involved in this sector (mainly engineers, architects, local planners and building companies) [5]. In particular, measures and data for assessing building energy efficiency should be determined by using environmental measurements and building simulation tools [6]. The evaluation of a building global energy performance index ( $E P_{\mathrm{gl}}$ expressed in $\mathrm{kWh} / \mathrm{m}^{2}$. year) is the first step to identify more effective strategies, interventions and criteria to improve its energy performance [7]. $E P_{\mathrm{gl}}$ is displayed in the Energy Performance Certificate (EPC) considering the rules contained in the norms UNI TS 11300 and it is the sum of the $E P_{\mathrm{H}}$, energy performance index in the heating seasons, and $\mathrm{EP}_{\mathrm{W}}$ Energy performance index for domestic hot water production [8]. Indeed, EPC in Italy integrate the energy consumption assessment [9] with information about the environmental impact derived both from the buildings themselves and the type of materials contained in the buildings. This approach foresees the use of a Life Cycle Assessment (LCA) method for assessing the environmental impact of materials and plants over their life cycles [10].

Considering energy efficiency economic costs, as stated by the European Parliament in 2010, with the Energy Performance of Buildings Directive (EPBD), assessing economic costs of interventions is essential for the choice of optimal solutions to decrease building energy consumption [11]. Cost-benefit analysis is used in many fields as a methodology for comparing economic sustainability of possible strategies and interventions that could be adopted, in order to highlight the best feasible alternative [12]. Additionally, cost-benefit analysis is not to be confused with the life cycle cost (LCC), identified as the sum of the total costs of design, construction, installation, operation, management and disposal; conversely cost-benefit analysis is typically used as a decision making tool for the comparison of different solutions for improving energy performance based on cost of investment [13].

Based on the above considerations, this paper investigates the cost-benefit analysis of energy efficiency retrofitting interventions on public buildings, highlighting more effective interventions according to building characteristics and features, by the estimation and comparison of the economic cost and the energy efficiency improvement for each considered retrofitting intervention.

Energy-demand retrofitting is considered as an effective way to accelerate the low-energy transformation of building stock in accordance with adopted EU Directives. Indeed, existing Buildings cover about $75 \%-85 \%$ of the building stock today and in the next fifty years [14].

In accordance with Wang and Holmberg [15], very little methodology is currently being implemented out to efficiently select and evaluate the retrofitting techniques. In any case, Paiho et al. [16] designed for Russian residential buildings some cost analysis-based retrofitting strategies to implement building installation system renovations, while Sahin et al. [17] showed how the energy retrofits in historical buildings should be managed in a transdisciplinary approach.

Within the energy efficiency retrofitting of existing buildings Camprubí et al. [18] highlighted three main types of interventions: passive structures (insulating the passive components of the building), active elements (upgrading heating systems) and management/information skills (to improve energy habits of residents).

Different typologies of interventions for improving energy efficiency in new and existing buildings have been considered by the authors in different previous studies, which considered both renewable energy systems [19-21] and the planning of strategies for the minimization of energy consumption [22-25]. Cost-benefit analysis allows public administrations to highlight which retrofitting intervention could be most financially feasible for each considered public building, subject to available budgets. 


\section{Materials and Methods}

In order to analyze cost and benefits of all the main intervention typologies, four public buildings have been selected as case studies. The four building typologies include different territorial contexts and ages of construction. The considered territorial contexts take account of suburban areas, urban zones and old towns while the building age of construction varies from 16th century to the present day. The application of the methods in these different contexts allows for the consideration of most Italian building stock circumstances.

Many feasible interventions have been considered for each building, analyzing their economic costs and benefits in terms of energy efficiency improvement, and trying to obtain general indications that could be useful for comparing different interventions on other buildings that need an energy requalification. Indeed, for buildings under landscaping or historical constraints not all the energy efficiency interventions or thermal systems could be installed [26].

All four of the analyzed buildings have been selected from the same geographical area within the same climate zone in order to remove $E P_{\mathrm{gl}}$ variability caused by climate parameters [27]. The buildings analyzed are Villa Sciarra, a historic 16th century building located in a suburban area and subjected to external constraints by the local Superintendence; the Italian Ministry of Economic Development (MiSE), a historic 20th century building located in the centre of an urban area; the Italian Space Agency (ASI), a modern building of recent construction; and the Ex Banco Napoli Building, a historic 17th century building located in the historic centre of an urban area and then subjected to local constraints (Figure 1). Villa Sciarra is one of the historic villas of Rome realized in 1549 and it is the Italian site of the Germanic Studies Institute. It is located on the slopes of the Janiculum hill between the neighborhoods of Trastevere and Monteverde. The building is currently dedicated to archives, offices and libraries. The second building, MiSE, is an administrative apparatus of the Italian government dealing with production activities, international trade, communication and energy. The building was created between 1928 and 1932, and is under architectural constraints. The ASI building was recently built (2012), its envelope is mainly composed of glass and includes some water pools under the building, which provide both an aesthetic and functional role. The Ex Banco Napoli building is the administrative offices from the Chamber of Deputies and was realized in 1600; it is located on the historic center of Rome and subjected to planning and architectural restrictions. Local constraints and territorial contexts of each building were analyzed using geographic information system (GIS) software that allows one to superimpose satellite images with different information layers [28-31]. The literature also shows that the comparison between buildings is a useful method to improve their level of energy efficiency, highlighting energy consumptions and possible interventions in different context [13].

For each pilot building feasible interventions for improving energy efficiency have been considered. The selected interventions include scenarios that are applicable to the urban context in which the buildings are located and which can be integrated with the existing building. Then, energy efficiency improvement and economic costs have been assessed for each intervention, in order to estimate the options with the best cost-benefit ratio. The energy efficiency improvement for each proposed intervention has been simulated through a double analysis of the building $E P_{\mathrm{gl}}$, before and after the intervention, in order to quantify the changes [27]. All existing public buildings are compulsorily required to provide an energy certificate to States Members by the EPBD [13]. $E P_{\mathrm{gl}}$ values have been assessed using STIMA 10 , a software able to calculate $E P_{\mathrm{H}}, E P_{\mathrm{W}}$ and the final $E P_{\mathrm{gl}}$ starting from climate/geographical parameters and technical data describing the investigated buildings [32].

Moreover, a cost-benefit analysis was carried out based on the average cost, which was established by obtaining quotes from five suitable companies, for each proposed intervention. A cost-benefit analysis converts the performance achieved by the building in monetary figures and is more useful than a simple economic framework [33]. 


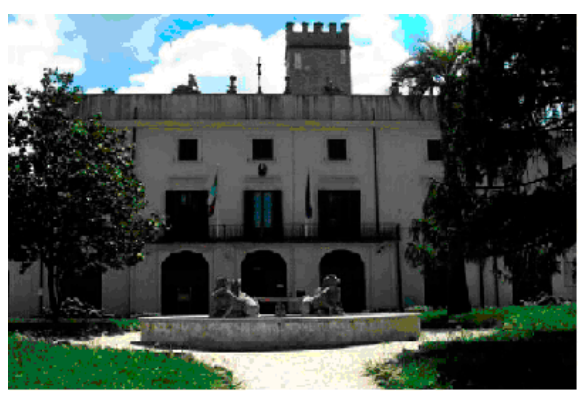

(a)

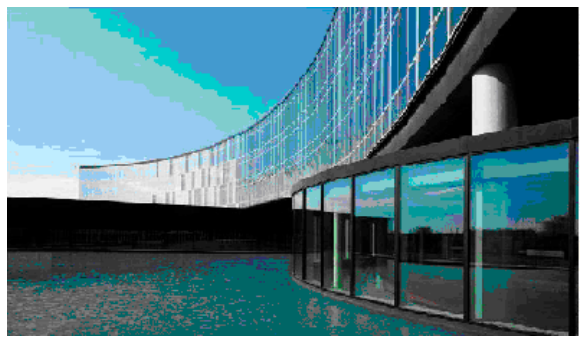

(c)

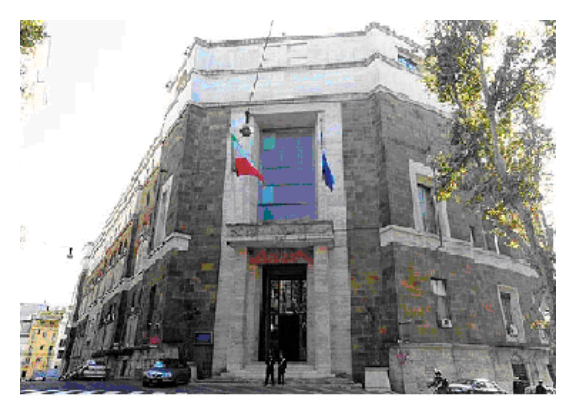

(b)

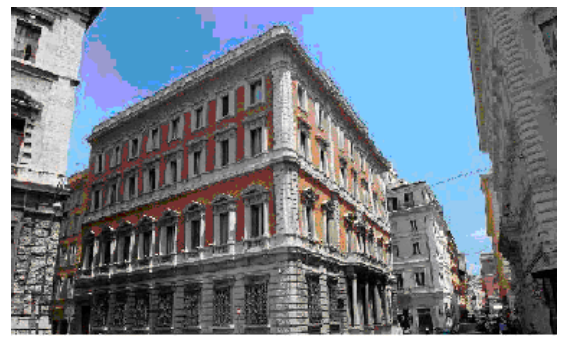

(d)

Figure 1. The four analyzed public buildings: (a) Villa Sciarra and (b) Italian Ministry of Economic Development (MiSE) facades; (c) Italian Space Agency (ASI) and (d) Ex Banco Napoli Building facades.

\subsection{Actual Situation of Plant-System Building}

Villa Sciarra is a two storey masonry load bearing building, with a basement and a flat roof; the building is equipped with a traditional heating system plant with radiators. MiSE is also a load bearing masonry building and has eight floors where most of the spaces are offices. The building includes a photovoltaic (PV) system and fixtures with insulated glass. The ASI building is located within the university campus of Tor Vergata, was built with mixed masonry and does not have any renewable energy system. Ex Banco Napoli is a load bearing masonry structure and has five floors of offices and a basement designed for technical rooms.

3D building models have been established by inserting the survey data in STIMA 10 software including the characteristics of the horizontal and vertical facades and pinpointing opaque and transparent surfaces in order to define the degree of insulation provided by each component of each building envelope. To complete the base virtual models, current building operating system features were added, so as to simulate the conditions ante operam and post operam of each proposed intervention. Table 1 lists the main data about the actual situation of the four analyzed buildings that influence their energy performances.

Table 1. Actual situation characteristics of the analyzed buildings.

\begin{tabular}{ccccc}
\hline Characteristics & Villa Sciarra & MiSE & ASI & Ex Banco Napoli \\
\hline Gross heated volume $\left(\mathrm{m}^{3}\right)$ & 8207 & 124,727 & 113,770 & 57,536 \\
Useful surface $\left(\mathrm{m}^{2}\right)$ & 7500 & 18,252 & 28,600 & 5575 \\
Surface/volume ratio & 0.46 & 0.25 & 0.37 & 0.09 \\
Storey height $(\mathrm{m})$ & 3.85 & 3 & 3 & 3 \\
\hline
\end{tabular}

The assessed current energy performance data are reported in Figure 2 and has been calculated by inserting the data gathered during specific surveys on STIMA 10 Software (Idronica Line-Watts Industries Italia S.r.l., Biassono, Italy). 
Villa Sciarra

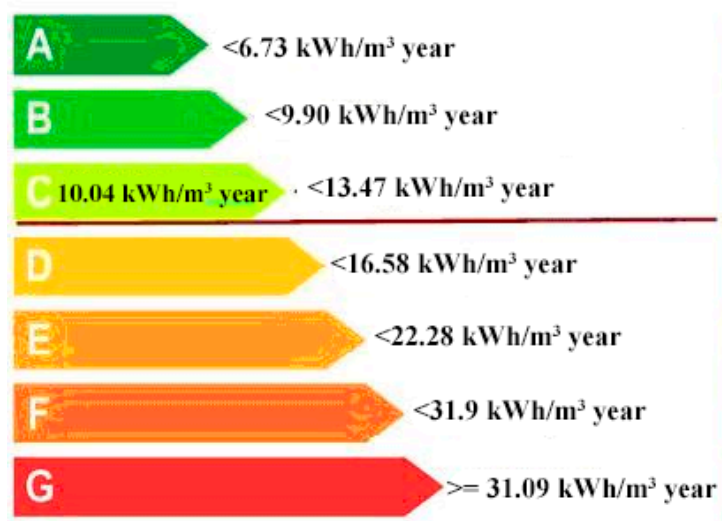

ASI Rome

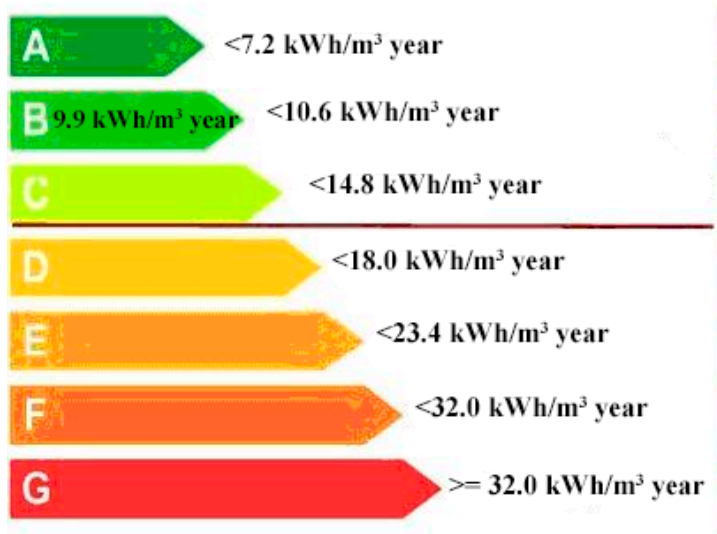

MiSE

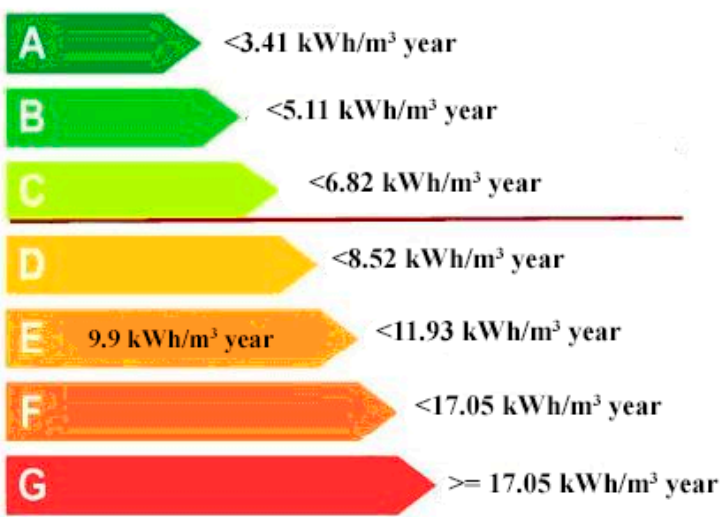

Ex Banco Napoli

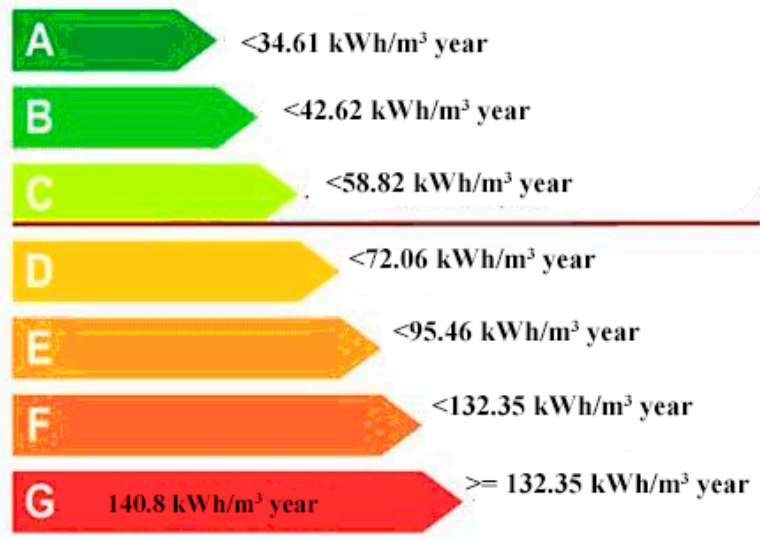

Figure 2. Actual energy performance of the analyzed buildings ( $E P_{\mathrm{gl}}$ values).

\subsection{Proposed Interventions: Villa Sciarra}

Since Villa Sciarra is located within one of the public gardens of Rome, the chosen interventions were guided by the constraints imposed by the Superintendent that denied the possibility to intervene outside the building. The first identified intervention is the ceiling indoor insulation as detailed in Figure 3, that entails a ceiling trasmittance $(U)$ decrease from $0.416 \mathrm{~W} / \mathrm{m}^{2} \cdot \mathrm{K}$ to $0.229 \mathrm{~W} / \mathrm{m}^{2} \cdot \mathrm{K}$ (Tables 2-4). Moreover, the replacement of single glazed windows with insulated glass unit, as shown in Table 5, has been considered as second feasible intervention, estimating a $U$ decrease from $5.1 \mathrm{~W} / \mathrm{m}^{2} \cdot \mathrm{K}$ to $2.842 \mathrm{~W} / \mathrm{m}^{2} \cdot \mathrm{K}$. Vapor permeability of each considered layer has been calculated for relative humidity ranges up to $50 \%$.

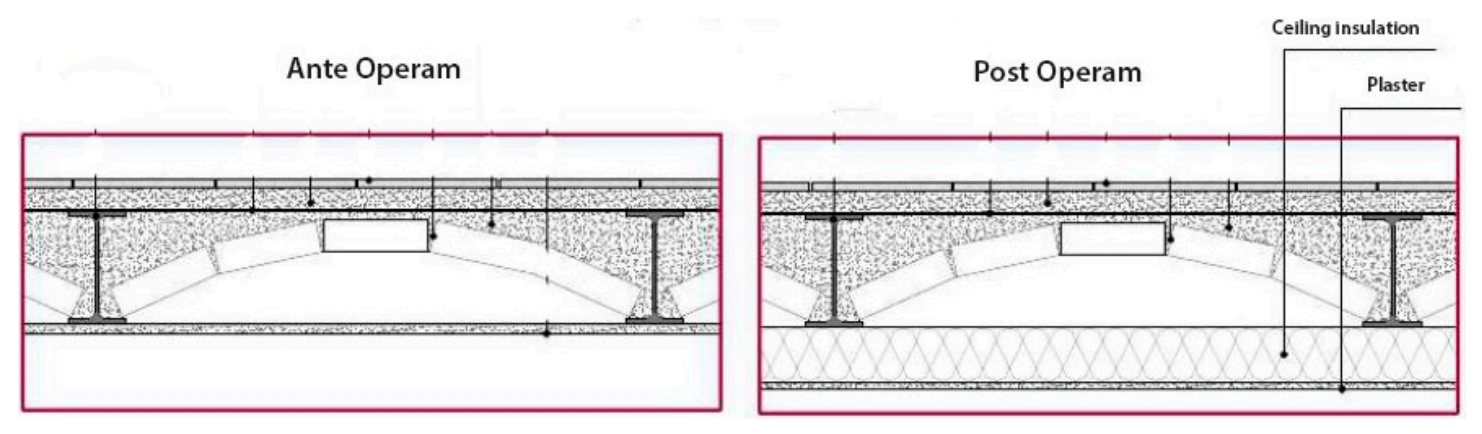

Figure 3. Villa Sciarra ceiling stratigraphy before and after the insulation intervention. 
Table 2. Villa Sciarra floor stratigraphy before intervention.

\begin{tabular}{cccccccc}
\hline $\begin{array}{c}\text { Description Layer } \\
\text { (From Top to Bottom) }\end{array}$ & $\boldsymbol{s}$ & $\mathbf{L a m b d a}$ & $\boldsymbol{C}$ & $\mathbf{M . S}$ & $\mathbf{P}<\mathbf{5 0}^{\circ} \cdot \mathbf{1 0 1}^{\mathbf{2}}$ & $\mathbf{C . S .}$ & $\boldsymbol{R}$ \\
\cline { 2 - 7 } & $\mathbf{m m}$ & $\mathbf{W} / \mathbf{m} \cdot \mathbf{K}$ & $\mathbf{W} / \mathbf{m}^{\mathbf{2}} \cdot \mathbf{K}$ & $\mathbf{~ k g} / \mathbf{m}^{\mathbf{2}}$ & $\mathbf{~ k g} / \mathbf{m s} \cdot \mathbf{P a}$ & $\mathbf{J} / \mathbf{k g} \cdot \mathbf{K}$ & $\mathbf{m}^{\mathbf{2}} \cdot \mathbf{K} / \mathbf{W}$ \\
\hline Adduttance top & 0 & - & 7.7 & - & - & 0 & 0.13 \\
Tiled floor & 10 & 2.9 & 290 & 23 & 0.019 & 840 & 0.003 \\
Lime mortar or lime cement & 30 & 0.9 & 30 & 54 & 8.5 & 1000 & 0.033 \\
Bitumen & 5 & 0.17 & 34 & 6 & 0 & 1000 & 0.029 \\
Concrete aggregates & 85 & 1.263 & 14.853 & 170 & 2.6 & 1000 & 0.067 \\
Solid brick tile & 45 & - & 6.667 & 216 & 20.57 & 840 & 0.15 \\
Air & 50 & 0.026 & 0.52 & 0.07 & 193 & 1008 & 1.923 \\
Lime plaster & 20 & 0.7 & 35 & 28 & 18 & 1000 & 0.029 \\
Adduttance lower & 0 & - & 25 & - & - & 0 & 0.04 \\
\hline
\end{tabular}

Table 3. Villa Sciarra floor stratigraphy after intervention.

\begin{tabular}{|c|c|c|c|c|c|c|c|}
\hline \multirow{2}{*}{$\begin{array}{l}\text { Description Layer } \\
\text { (From Top to Bottom) }\end{array}$} & Thickness & $\begin{array}{c}\text { Thermal } \\
\text { Conductivity }\end{array}$ & $\begin{array}{l}\text { Thermal } \\
\text { Conductance }\end{array}$ & $\begin{array}{l}\text { Mass } \\
\text { Surface }\end{array}$ & $\begin{array}{c}\text { Vapor } \\
\text { Permeability }\end{array}$ & $\begin{array}{l}\text { Specific } \\
\text { Heat }\end{array}$ & $\begin{array}{l}\text { Thermal } \\
\text { Resistance }\end{array}$ \\
\hline & $\mathrm{mm}$ & $\mathbf{W} / \mathbf{m} \cdot \mathbf{K}$ & $\mathrm{W} / \mathrm{m}^{2} \cdot \mathbf{K}$ & $\mathrm{kg} / \mathrm{m}^{2}$ & $\mathrm{~kg} / \mathrm{ms} \cdot \mathrm{Pa}$ & $\mathrm{J} / \mathrm{kg} \cdot \mathrm{K}$ & $\mathrm{m}^{2} \cdot \mathrm{K} / \mathrm{W}$ \\
\hline Tiled floor & 10 & 2.9 & 290 & 23 & 0.019 & 840 & 0.003 \\
\hline Lime mortar or lime cement & 30 & 0.9 & 30 & 54 & 8.5 & 1000 & 0.033 \\
\hline Bitumen & 5 & 0.17 & 34 & 6 & 0 & 1000 & 0.029 \\
\hline Still air medium thickness & 50 & 0.026 & 0.52 & 0.07 & 193 & 1008 & 1.923 \\
\hline Extruted polystirene foam & 80 & 0.041 & 0.509 & 2.4 & 2.08 & 1200 & 1.966 \\
\hline Lime and gypsum plaster & 20 & 0.7 & 35 & 28 & 18 & 1000 & 0.029 \\
\hline Adduttance lower & 0 & - & 25 & - & - & 0 & 0.04 \\
\hline
\end{tabular}

Table 4. Villa Sciarra ceiling thermal performance before and after intervention.

\begin{tabular}{ccc}
\hline Thermal Performance & Before Intervention & After Intervention \\
\hline Thickness $(\mathrm{mm})$ & 245 & 325 \\
Resistance $\left(\mathrm{m}^{2} \cdot \mathrm{K} / \mathrm{W}\right)$ & 2.405 & 4.371 \\
Transmittance $\left(\mathrm{W} / \mathrm{m}^{2} \cdot \mathrm{K}\right)$ & 0.416 & 0.229 \\
Periodic thermal transmittance $\left(\mathrm{W} / \mathrm{m}^{2} \cdot \mathrm{K}\right)$ & 0.60 & 0.11 \\
Heat capacity for unit area (top) $\left(\mathrm{kJ} / \mathrm{m}^{2} \cdot \mathrm{K}\right)$ & 74,327 & 73,077 \\
Heat capacity for unit area $($ bottom $)\left(\mathrm{kJ} / \mathrm{m}^{2} \cdot \mathrm{K}\right)$ & 48,715 & 30,524 \\
Attenuation factor & 0.40 & 0.29 \\
Surface mass $\left(\mathrm{kg} / \mathrm{m}^{2}\right)$ & 469 & 471 \\
Phase shift $(\mathrm{h})$ & 6.25 & 7.19 \\
\hline
\end{tabular}

Table 5. Villa Sciarra fixtures stratigraphy before and after intervention.

\begin{tabular}{ccc}
\hline Parameter & Before Intervention & After Intervention \\
\hline Glass surface $\left(\mathrm{m}^{2}\right)$ & 2.312 & 2.067 \\
Frame surface $\left(\mathrm{m}^{2}\right)$ & 0.548 & 0.793 \\
Glass perimeter length $(\mathrm{m})$ & 17.24 & 16.28 \\
Glass transmittance $\left(\mathrm{W} / \mathrm{m}^{2} \cdot \mathrm{K}\right)$ & 5.751 & 2.704 \\
Frame transmittance $\left(\mathrm{W} / \mathrm{m}^{2} \cdot \mathrm{K}\right)$ & 2.39 & 1.971 \\
linear thermal transmittance $\left(\mathrm{W} / \mathrm{m}^{2} \cdot \mathrm{K}\right)$ & 0 & 0.060 \\
Total transmittance $\left(\mathrm{W} / \mathrm{m}^{2}\right)$ & 5.1 & 2.842 \\
Solar energy transmittance & 0.85 & 0.67 \\
Reduction coefficient frame surface & 0.191 & 0.277 \\
Internal surface resistance per unit $\left(\mathrm{m}^{2} \cdot \mathrm{K} / \mathrm{W}\right)$ & 0.130 & 0.130 \\
External surface resistance per unit $\left(\mathrm{m}^{2} \cdot \mathrm{K} / \mathrm{W}\right)$ & 0.04 & 0.04 \\
Internal surface conductance per unit $\left(\mathrm{W} / \mathrm{m}^{2} \cdot \mathrm{K}\right)$ & 7.7 & 7.7 \\
External surface conductance per unit $\left(\mathrm{W} / \mathrm{m}^{2} \cdot \mathrm{K}\right)$ & 25 & 25 \\
Total thermal resistance $\left(\mathrm{m}^{2} \cdot \mathrm{K} / \mathrm{W}\right)$ & 0.196 & 0.352 \\
\hline
\end{tabular}

For improving a building $E P_{\mathrm{gl}}$ value and consequentially its energy efficiency, it is necessary to evaluate the energy used for winter heating and summer cooling and its related management system 
costs. The existing heating and cooling plant of Villa Sciarra uses fan coils to distribute thermal energy from a water based system. The reverse-cycle air/water based air-conditioning system which heats fluid in winter and cools fluid in summer, is powered by electricity from the grid. To evaluate the exact consumption of this heating, ventilating and air conditioning (HVAC) system, an analysis of the building electricity consumption was completed using data provided from four consecutive years (from 2009 to 2012). From this analysis, the energy consumption was quantified, which is shown in Table 6.

Table 6. Villa Sciarra electricity consumptions and related economic costs.

\begin{tabular}{|c|c|c|c|c|c|c|c|c|}
\hline \multirow{2}{*}{ Month } & \multicolumn{2}{|c|}{2009} & \multicolumn{2}{|c|}{2010} & \multicolumn{2}{|c|}{2011} & \multicolumn{2}{|c|}{2012} \\
\hline & MWh & $€$ & MWh & $€$ & MWh & $€$ & MWh & $€$ \\
\hline January & 10.01 & 1693 & 12.17 & 2341 & \multirow{2}{*}{9.56} & \multirow{2}{*}{3646} & 10.53 & 2146 \\
\hline February & 10.86 & 1844 & 9.25 & 1536 & & & 10.04 & 2046 \\
\hline March & 9.98 & 1730 & 9.67 & 1604 & 9.71 & 1555 & 10.43 & 2109 \\
\hline April & 8.60 & 1472 & 7.52 & 1257 & 8.53 & 1452 & 2.49 & 541 \\
\hline May & 6.63 & 1136 & 7.82 & 1307 & 7.88 & 1361 & 5.96 & 1341 \\
\hline June & 9.09 & 1888 & 8.01 & 1337 & 7.90 & 1435 & 6.59 & 1497 \\
\hline July & 8.22 & 1280 & 9.33 & 1553 & 6.47 & 2189 & 8.90 & 2022 \\
\hline August & 8.00 & 1245 & 9.77 & 1981 & 5.36 & 1579 & 6.35 & 1445 \\
\hline September & 7.68 & 1288 & 9.89 & 1788 & 7.14 & 1445 & 7.40 & 1681 \\
\hline October & 7.27 & 1403 & 8.80 & 1462 & 6.14 & 1242 & 7.19 & 1635 \\
\hline November & 9.07 & 1524 & 9.13 & 1519 & 6.54 & 1845 & 4.35 & 989 \\
\hline December & 9.28 & 1664 & 1.02 & 1632 & 8.91 & 1815 & 9.81 & 7404 \\
\hline Total & 104.73 & 18,172 & 11.133 & 19,323 & 93.73 & 19,568 & 90.09 & 24,862 \\
\hline
\end{tabular}

An analysis of electricity consumption for lighting and HVAC was defined by reference costs reported in the data provided by the building owners. The results highlight a consumption for HVAC system of about 20-25 MWh/year (Figure 4).

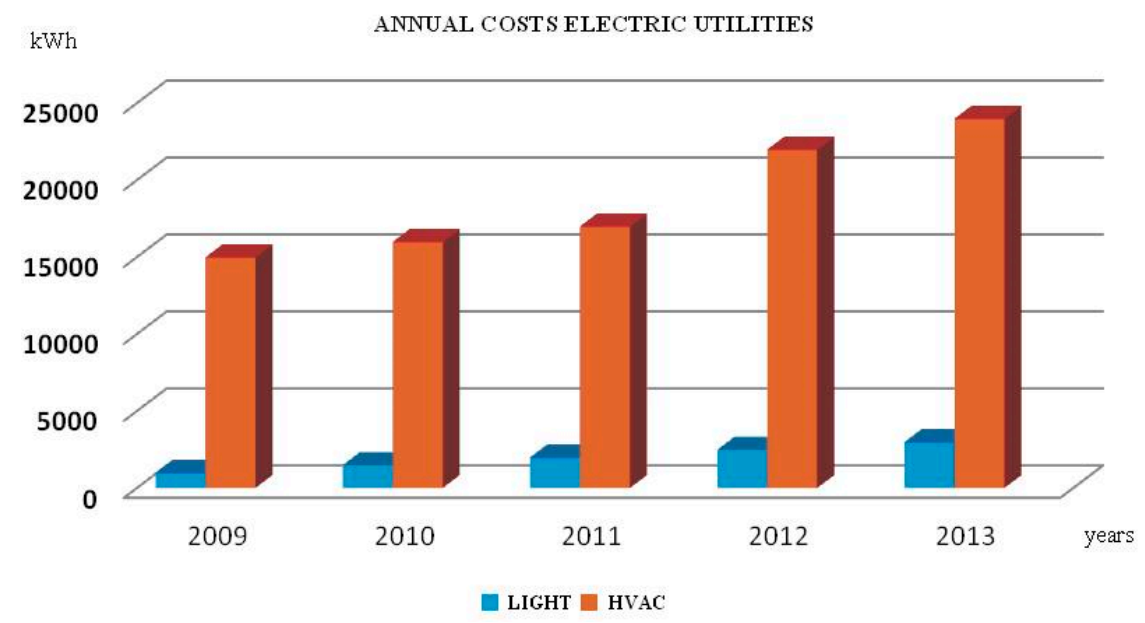

Figure 4. Annual consumptions for electric utilities (light and heating, ventilating and air conditioning (HVAC)) uses. 
Consequentially, to optimize energy efficiency of the existing HVAC system, interventions which explored adaptation and replacement were evaluated. Considering that the territorial context of Villa Sciarra is a public garden, the proposal is to install a vertical ground loop geothermal system, with a heat pump inverter, to provide a more energy efficient air-conditioning system (Figure 5). Indeed, vertical probes are not invasive and do not involve external works that could compromise the building and the surrounding park. Additionally, this system does not require a substitution of the existing heating and cooling energy distribution systems.

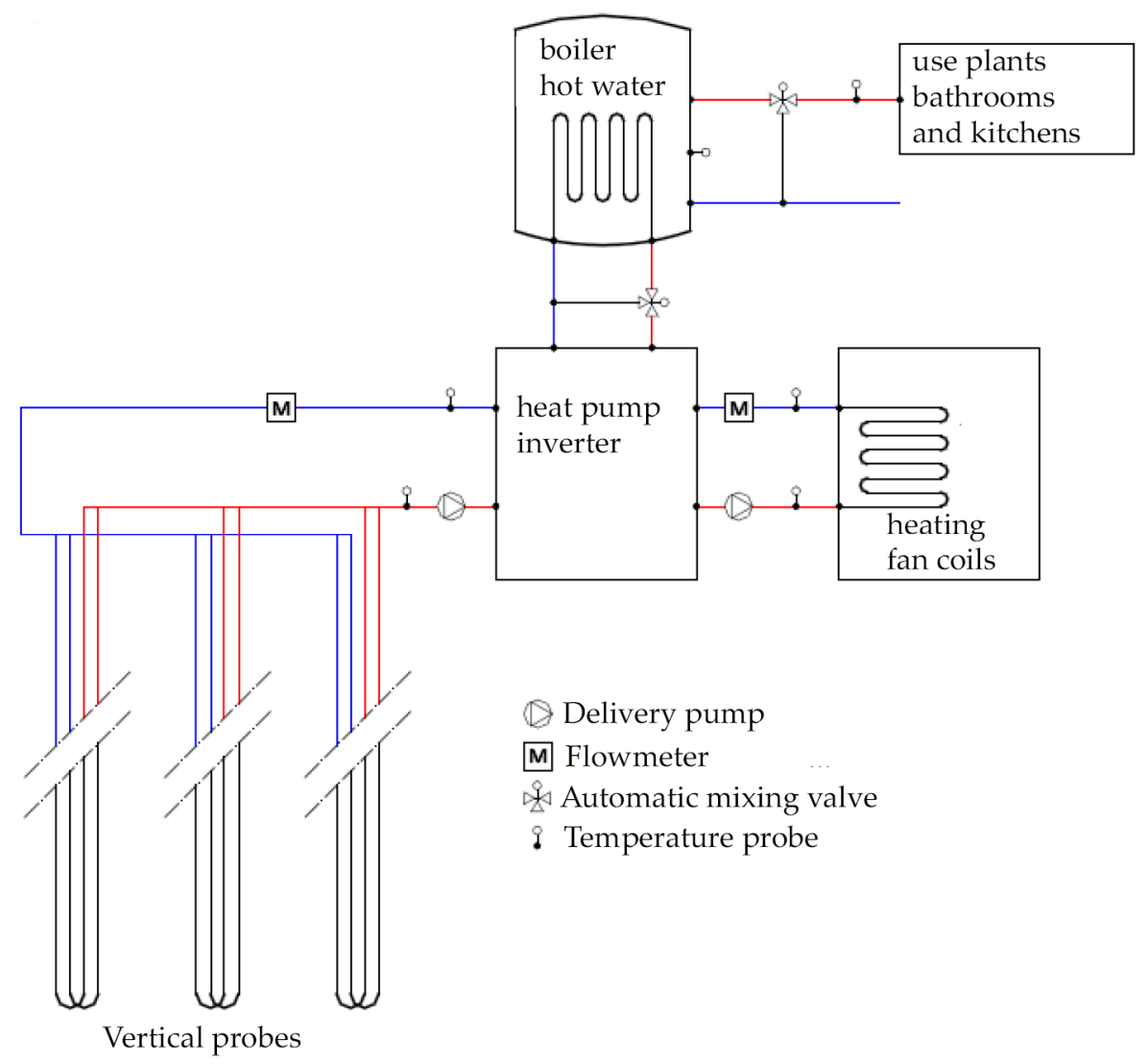

Figure 5. Geothermal plant scheme.

The adoption of a system with vertical geothermal probes could be chosen in public or private garden contexts since it involves vertical boreholes that will not harm the surrounding park; moreover, vertical boreholes will ensure the reduction of the building energy consumption due to its higher energy efficiency according with the results obtained by the $E P_{\mathrm{gl}}$ assessments before and after its installation.

\subsection{Proposed Interventions: Italian Ministry of Economic Development}

The building is currently equipped with a PV system, installed in 2010, which produces about $48 \mathrm{MWh}$ /year. Moreover, in 2009 single glazed windows on the sixth, seventh and eighth floors were replaced with low emission double-glazed units.

An analysis of the historical constraints of the urban area where the building is located pinpoints two feasible interventions to achieve the limit of $E P_{\mathrm{gl}}$ values established by law: the introduction of thermostatic valves and the replacement of single pane windows with low emissivity (low-e) glazing with aluminium frames in the floors not included in the 2009 interventions. The first intervention consists of the installation of thermostatic valves in the fan coils of each zone as devices for heating control giving the possibility to regulate the temperature of each room according with its real use. 
The use of thermostatic valves brings an average energy saving from $10 \%$ to $50 \%$ [34] and allows a reduction of hot water use.

Considering the second intervention, low-e glazing significantly reduces heat loss but does not significantly reduce visible light transmittance, promoting the use of natural daylight within the building. Their inclusion (Tables 7 and 8 and Figure 6) allows an improvement of the environmental comfort and sustainability because it reduces the risk of condensation on the internal pane, as well as the heat transmission from outdoor to indoor during summer months. In addition, this intervention brings light and solar heat in the winter, improving energy efficiency in the existing building considered as one of the main challenges for obtaining GHG emissions reduction [35].

The chosen low-e glass typology meets the requirement imposed by Italian normative for existing buildings, requiring that $U$ values for glazing should not be higher than $2 \mathrm{~W} / \mathrm{m}^{2} \cdot \mathrm{K}$ in climatic zone D.

Table 7. MiSe fixtures stratigraphy before (single glasses) and after (low-e glasses) intervention.

\begin{tabular}{cccccc}
\hline Description Layer & Thickness & $\begin{array}{c}\text { Thermal } \\
\text { Conductance }\end{array}$ & Mass Surface & $\begin{array}{c}\text { Vapor } \\
\text { Permeability }\end{array}$ & $\begin{array}{c}\text { Thermal } \\
\text { Resistance }\end{array}$ \\
\cline { 2 - 6 } & $\mathbf{m m}$ & $\mathbf{W} / \mathbf{m}^{\mathbf{2}} \cdot \mathbf{K}$ & $\mathbf{k g} / \mathbf{m}^{\mathbf{2}}$ & $\mathbf{k g} / \mathbf{m s} \cdot \mathbf{P a}$ & $\mathbf{m}^{\mathbf{2}} \cdot \mathbf{K} / \mathbf{W}$ \\
\hline Glass (before) & 4 & 538.05 & 2500 & 0 & 0.002 \\
Glass (after) & 4 & 250 & 2500 & 0.004 & 0.17 \\
Air (after) & 15 & 5.882 & 1.3 & 0 & 0.176 \\
Low-e glass (after) & 6 & 5.67 & 2500 & 0 & 0.004 \\
Glass (after) & 4 & 250 & 2500 & & \\
\hline
\end{tabular}

Table 8. MiSE fixtures thermal performance before and after intervention.

\begin{tabular}{ccc}
\hline Thermal Performance & Before Intervention & After Intervention \\
\hline Total thickness $(\mathrm{mm})$ & - & 29 \\
Total thermal resistance $\left(\mathrm{m}^{2} \cdot \mathrm{K} / \mathrm{W}\right)$ & 0.167 & 0.524 \\
Total transmittance $\left(\mathrm{W} / \mathrm{m}^{2} \cdot \mathrm{K}\right)$ & 5.993 & 1.907 \\
Internal surface conductance per unit $\left(\mathrm{W} / \mathrm{m}^{2} \cdot \mathrm{K}\right)$ & 8 & 8 \\
External surface conductance per unit $\left(\mathrm{W} / \mathrm{m}^{2} \cdot \mathrm{K}\right)$ & 25 & 25 \\
Internal surface resistance per unit $\left(\mathrm{m}^{2} \cdot \mathrm{K} / \mathrm{W}\right)$ & 0.125 & 0.13 \\
External surface resistance per unit $\left(\mathrm{m}^{2} \cdot \mathrm{K} / \mathrm{W}\right)$ & 0.04 & 0.04 \\
\hline
\end{tabular}

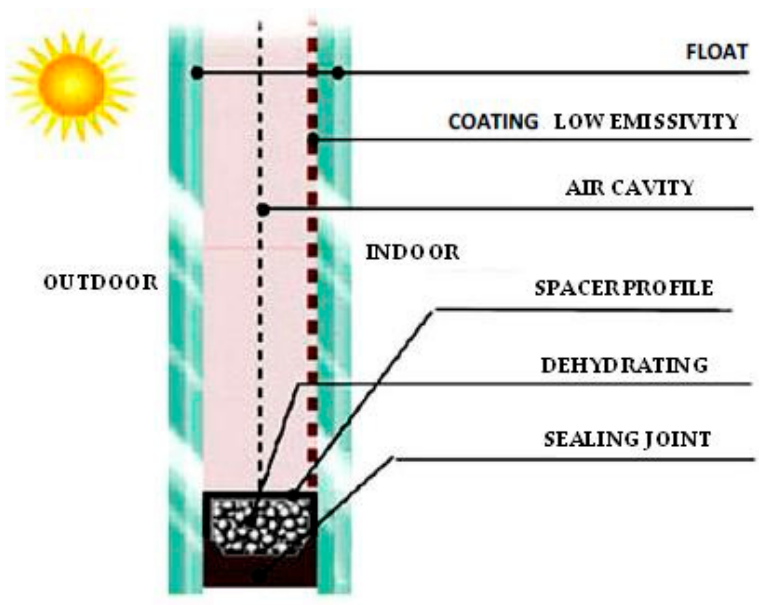

Figure 6. Operation of low-emissivity glass.

\subsection{Proposed Interventions: Italian Space Agency}

The energy used for ASI building winter heating and summer cooling and its related economic costs have been assessed for improving energy efficiency of the building. 
The installed heating system includes a burner powered by methane and three pressurized boilers with a thermal output of $1200 \mathrm{~kW} / \mathrm{t}$ each. The generators have been dimensioned on the basis of thermal needs of the users providing a minimum reserve of about the $25 \%$ of the maximum demand. The boilers supply the domestic hot water system, heat exchangers of retrieval system, heating and air conditioning systems. An analysis of electricity consumption data provided by the building owners was completed to evaluate the exact consumption of the HVAC system. The obtained results, reported in Table 9, pinpointed an average monthly consumption of 158.08 MWh and an average monthly cost of $€ 44,385$.

Table 9. ASI electricity consumption and related economic costs.

\begin{tabular}{ccc}
\hline Month & Energy Consumptions (MWh) & Economic Costs (€) \\
\hline January & 132.67 & 35,450 \\
\hline February & 129.06 & 36,065 \\
\hline March & 135.11 & 37,337 \\
\hline April & 126.49 & 33,290 \\
\hline May & 152.51 & 41,500 \\
\hline June & 187.55 & 52,096 \\
\hline July & 199.74 & 59,880 \\
\hline August & 193.39 & 56,760 \\
\hline September & 166.16 & 47,084 \\
\hline Total & 1422.70 & 399,466
\end{tabular}

Starting from these findings, the identification of the intervention was based on the integration of RES in order to significantly reduce the annual electric bill, which was approximately $€ 40,000 /$ month In particular, two feasible interventions have been considered: the installation of a $210 \mathrm{~kW}$ PV system and a trigeneration plant aimed at ensuring simultaneously electric and thermal energy for heating in winter and cooling during the summer.

The total available surface for the installation of PV panels is $4000 \mathrm{~m}^{2}: 1500 \mathrm{~m}^{2}$ on the parking roofs and $2500 \mathrm{~m}^{2}$ on the flat roof of some buildings as specified in Figure 7.

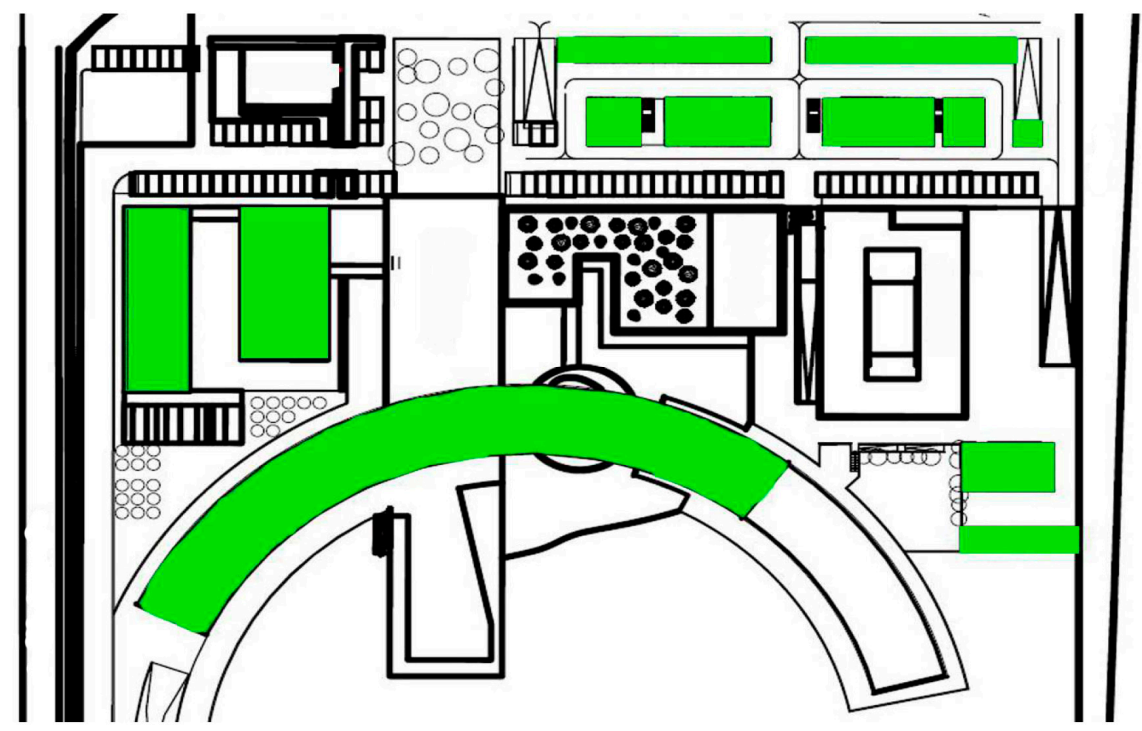

Figure 7. ASI building available surfaces for the installation of photovoltaic (PV) panels (in green). 
The annual energy production of this PV plant was estimated as to $280 \mathrm{MWh} /$ year, considering the latitude and the average annual insolation of the area as well and the overall efficiency of the system. All the PV panels have been oriented to the south, but according to architectural integration patterns, only $35 \%$ of them has been installed with a tilt of $30^{\circ}$, while the remaining $65 \%$ has been placed on the horizontal plane with a tilt of $0^{\circ}$.

The trigeneration system, located in front of the building in a special sound-proof containers, uses a combined heat and power (CHP) system with a natural gas combustion engine and a group of lithium bromide absorbers. Indeed, CHP technology can be adopted largely for industrial and civil sectors as an efficient alternative to traditional generation systems [36,37].

The considered trigeneration system produce $30 \%$ of electricity and $55 \%$ of thermal energy, with $15 \%$ of energy losses; in any case electrical energy produced by these two systems is less than the building energy needs. During the winter, heat recovered from the trigeneration system contributes jointly with the boilers to heat the building, while in the summer months the heat recovered from the exhaust gases is used to power the absorber able to deliver cooling energy to integrate the existing refrigeration system (Figure 8).

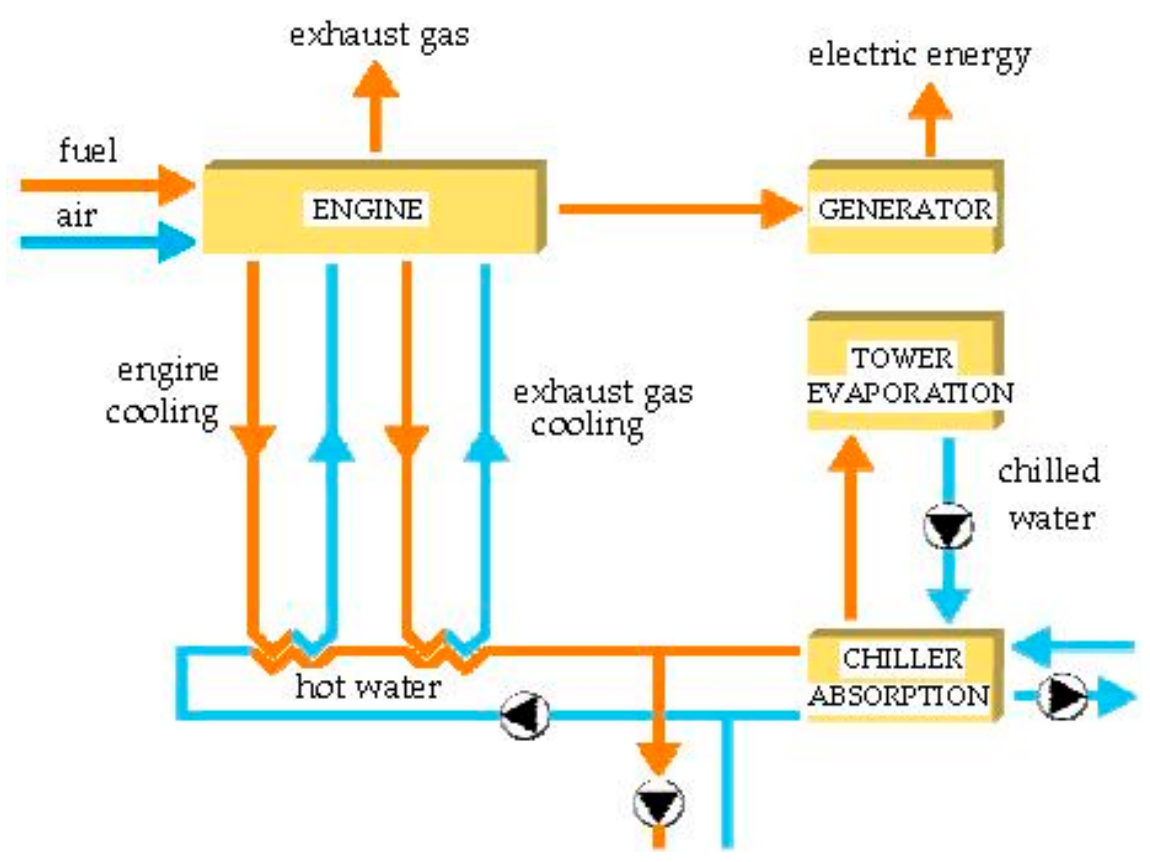

Figure 8. ASI trigeneration plant scheme.

\subsection{Proposed Interventions: Ex Banco Napoli}

Due to the regulatory constraints of the building and its urban context, the only feasible intervention proposed for the reduction of energy consumption in the Ex Banco Napoli building concerns the installation of solar collectors on the roof, to reduce energy consumption for heating water. The system is schematized in Figure 9 and includes 12 solar thermal collectors of $2.070 \mathrm{~m} \times 1.145 \mathrm{~m}$ with the following characteristics: antireflective treated glasses with high light transmission; a physical vapor deposition (PVD) highly selective and coated absorber for ensuring high energy absorption and low emissions; a hydraulic circuit with high heat transmission efficiency; a heat transfer fluid for heat absorption and transport; hydraulic connections to connect in series up to five thermal collectors (Table 10).

The solar thermal collectors have been arranged avoiding the shading coming from existing plants in the building terrace and minimising the visual impact of the new system. 


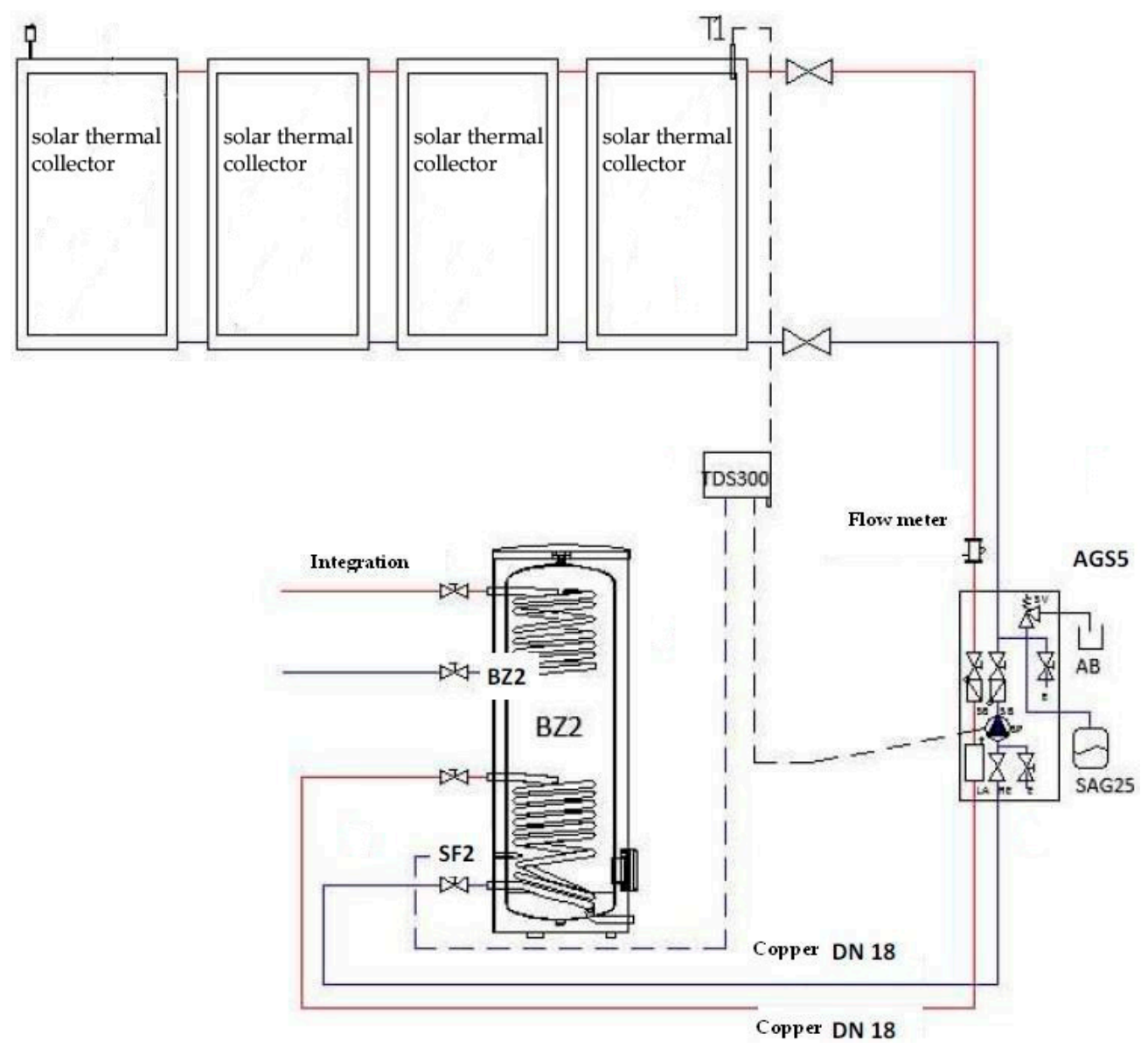

Figure 9. Ex Banco Napoli solar thermal collector system.

Table 10. Technical data of the solar collectors used in Ex Banco Napoli.

\begin{tabular}{ccc}
\hline Technical Date & Unit of Measure & Value \\
\hline Height & $\mathrm{m}$ & 2.07 \\
Width & $\mathrm{m}$ & 1.14 \\
Depth & $\mathrm{m}$ & 0.09 \\
Performance & $\%$ & 81.1 \\
Heat dispersion coefficient (a1) & $\mathrm{W} / \mathrm{m}^{2} \cdot \mathrm{K}$ & 3.653 \\
Heat dispersion coefficient (a2) & $\mathrm{W} / \mathrm{m}^{2} \cdot \mathrm{K}$ & 0.0146 \\
Weight & $\mathrm{kg}^{2}$ & 44 \\
Absorber area & $\mathrm{m}^{2}$ & 2.23 \\
Absorption percentage & $\%$ & $95 \pm 2$ \\
Emission percentage & $\%$ & $5 \pm 2$ \\
Maximum operating pressure & $\mathrm{Bar}$ & 10 \\
\hline
\end{tabular}

\section{Results and Discussion}

To make a preliminary cost-benefits analysis of the selected interventions in each considered public building in given weather conditions (Rome urban context), economic costs and energy efficiency improvement, have been compared. Energy efficiency improvement has been estimated as the difference of energy performance of each building before and after the proposed interventions.

Table 11 summarizes economic costs and $E P_{\mathrm{gl}}$ improvement estimated for each feasible intervention in Villa Sciarra. In addition, the cost for improving $E P_{\mathrm{gl}}$ of $1 \mathrm{kWh} / \mathrm{m}^{2}$ has been assessed in order to allow a comparison of the effective energy efficiency improvement among all the interventions. 
Table 11. Economic costs and $E P_{\mathrm{gl}}$ improvement for each considered intervention in Villa Sciarra.

\begin{tabular}{|c|c|c|c|c|}
\hline Interventions & $\begin{array}{c}E P_{\mathrm{gl}} \\
\left(\mathrm{kWh} / \mathrm{m}^{3} \cdot \text { year }\right)\end{array}$ & $\begin{array}{c}E P_{\text {gl }} \text { Improvement } \\
\left(\mathrm{kWh} / \mathrm{m}^{3} \cdot \text { year }\right)\end{array}$ & $\begin{array}{l}\text { Economic Costs } \\
(€)\end{array}$ & $\begin{array}{c}\text { Cost for Improvement } E P_{\mathrm{gl}} \\
\text { of } 1 \mathrm{kWh} / \mathrm{m}^{3} \cdot \text { year }(€)\end{array}$ \\
\hline Replacing fixtures & 9.94 & 0.10 & 28,350 & 283,500 \\
\hline Insulated roof & 9.70 & 0.34 & 71,775 & 211,103 \\
\hline Insulation floor & 9.28 & 0.76 & 37,950 & 49,934 \\
\hline Geothermal plant & 4.92 & 5.12 & 87,000 & 16,992 \\
\hline
\end{tabular}

Considering expenses estimated by the five different companies, economic costs incurred for both considered interventions in MiSE are reported in Tables 12 and 13 show the economic cost estimated for the two plants in ASI and Ex Banco Napoli buildings.

Table 12. Economic costs and $E P_{\mathrm{gl}}$ improvement for each considered intervention in MiSE.

\begin{tabular}{|c|c|c|c|c|}
\hline Interventions & $\begin{array}{c}E P_{\mathrm{gl}} \\
\left(\mathrm{kWh} / \mathrm{m}^{3} \cdot \text { year }\right)\end{array}$ & $\begin{array}{c}E P_{\mathrm{gl}} \text { Improvement } \\
\left(\mathrm{kWh} / \mathrm{m}^{3} \cdot \text { year) }\right.\end{array}$ & $\begin{array}{c}\text { Economic Costs } \\
(€)\end{array}$ & $\begin{array}{l}\text { Cost for Improvement } E P_{\mathrm{gl}} \\
\text { of } 1 \mathrm{kWh} / \mathrm{m}^{3} \cdot \text { year }(€)\end{array}$ \\
\hline Thermostatic valves & 6.30 & 2.79 & 65,380 & 23,434 \\
\hline Replacing fixtures & 3.90 & 5.19 & 494,646 & 95,308 \\
\hline
\end{tabular}

Table 13. Economic costs and $E P_{\mathrm{gl}}$ improvement for each considered intervention in ASI and Ex Banco Napoli.

\begin{tabular}{|c|c|c|c|c|}
\hline Interventions & $\begin{array}{c}E P_{\mathrm{gl}} \\
\left(\mathrm{kWh} / \mathrm{m}^{3} \cdot \text { year }\right)\end{array}$ & $\begin{array}{l}E P_{\mathrm{gl}} \text { Improvement } \\
\left(\mathrm{kWh} / \mathrm{m}^{3} \cdot \text { year }\right)\end{array}$ & $\begin{array}{c}\text { Economic Costs } \\
(€)\end{array}$ & $\begin{array}{c}\text { Cost for Improvement } E P_{\mathrm{gl}} \\
\text { of } 1 \mathrm{kWh} / \mathrm{m}^{3} \cdot \text { year }(\epsilon)\end{array}$ \\
\hline Insertion of PV panels (ASI) & 7.2 & 2.7 & 730,000 & 270,370 \\
\hline Trigeneration plant (ASI) & 7.9 & 2 & $2,270,000$ & $1,135,000$ \\
\hline $\begin{array}{l}\text { Solar collector system } \\
\text { (Ex Banco Napoli) }\end{array}$ & 83.1 & 57.7 & 75,099 & 1,302 \\
\hline
\end{tabular}

As for the systems installed in ASI, also in Ex Banco Napoli building the economic costs of installation involve a high initial investment which will then be recovered in few years (Table 13).

\subsection{Energy Efficiency Improvements}

Considering the overall energy efficiency improvement obtained by all the proposed interventions proposed in Villa Sciarra, a $4.62 \mathrm{kWh} / \mathrm{m}^{3}$. year $E P_{\mathrm{gl}}$ was obtained (A energy class) starting from a 10.04 value of $E P_{\mathrm{gl}}$ before the interventions. After replacing fixtures and installing thermostatic valves in MiSE, a B energy class was achieved getting an $E P_{\mathrm{gl}}$ value of $3 \mathrm{kWh} / \mathrm{m}^{3}$. year starting from an $E P_{\mathrm{gl}}$ of $9.09 \mathrm{kWh} / \mathrm{m}^{3}$. year (E energy class).

Due to the recent construction of ASI public building, the only proposed interventions were the installation of PV panels and a trigeneration system. From a starting $E P_{\mathrm{gl}}$ value of $9.9 \mathrm{kWh} / \mathrm{m}^{3}$. year (energy class B) in which ASI building was classified before these interventions, with the installation of $\mathrm{PV}$ panels and a trigeneration system, an $\mathrm{EP}_{\mathrm{gl}}$ value of $7 \mathrm{kWh} / \mathrm{m}^{3}$. year (energy class $\mathrm{A}$ ) was reached.

Finally, considering the obtained results in Ex Banco Napoli building, the installation of solar thermal collectors for hot water production allows to improve energy efficiency from an $E P_{\mathrm{gl}}$ of $140.8 \mathrm{kWh} / \mathrm{m}^{3}$. year ( energy class G) to an $E P_{\mathrm{gl}}$ of $83.1 \mathrm{kWh} / \mathrm{m}^{3}$. year (class E). Energy efficiency in buildings could also be assessed by estimating the reduction of GHG emissions [7,38]. As example, the installation of solar thermal collectors in Ex Banco Napoli building allows a reduction of $\mathrm{CO}_{2}$ emissions of 65 tons/year.

\subsection{Economic Cost Assessment}

Economic costs are summarized in Table 14, estimating for each the euro amounts per building square meters. 
Table 14. Economic costs for each considered intervention.

\begin{tabular}{cccc}
\hline Intervention & $\begin{array}{c}\text { Total Cost for Each } \\
\text { Intervention } \mathbf{( K \boldsymbol { ~ } )}\end{array}$ & $\begin{array}{c}\text { Intervention } \\
\text { Area } \mathbf{( m}^{\mathbf{2}} \mathbf{)}\end{array}$ & $\begin{array}{c}\text { Cost Per Building } \\
\text { Square Meter }\left(\boldsymbol{\epsilon} / \mathbf{m}^{\mathbf{2}}\right)\end{array}$ \\
\hline Trigeneration plant & 2270 & 28,600 & 79.37 \\
Replacing fixtures with low-e glasses & 494.646 & 18,252 & 27.09 \\
PV panels & 730 & 28,600 & 25.52 \\
Thermal solar collectors & 75.099 & 5575 & 13.46 \\
Geothermal plant & 87 & 7500 & 11.67 \\
Floor insulation & 71.775 & 7500 & 9.57 \\
Roof insulation & 37.95 & 7500 & 5.06 \\
Replacing fixtures with insulated glasses & 28.35 & 7500 & 3.78 \\
Thermostatic valves & 65.38 & 18,252 & 3.58 \\
\hline
\end{tabular}

Among the considered interventions, the results highlight that a trigeneration plant installation is the most expensive per $\mathrm{m}^{2}$ of building; replacing fixtures with low-e glasses an PV panels installation have a similar cost per square meter of the analysed buildings; the same could be said for geothermal plant and thermal solar collectors; Comparing costs for floor and roof insulation, the euro amount per square meter needed for the first one is almost twice the amount required for roof insulation; Replacing fixtures using insulated glasses costs much less than using low-e glasses and has a similar price per building square meter to thermostatic valves installation.

\subsection{Cost-Benefit Analysis}

Table 15 illustrates economic cost and $E P_{\mathrm{gl}}$ improvement for each feasible intervention, assessing the costs for improving $E P_{\text {gl }}$ of $1 \%$ in order to allow a cost-benefit analysis comparing economic costs an established percentage of energy efficiency improvement (1\%).

Table 15. Economic costs and $E P_{\text {gl }}$ percentage improvement for each considered intervention.

\begin{tabular}{cccc}
\hline \multirow{2}{*}{ Interventions } & $\boldsymbol{E} \boldsymbol{P}_{\mathbf{g l}}$ Improvement & Economic Costs & Cost for Improvement $\boldsymbol{E \boldsymbol { P } _ { \mathbf { g l } } \mathbf { ~ o f ~ } \mathbf { 1 } \%}$ \\
\cline { 2 - 4 } & $\boldsymbol{\%}$ & $\boldsymbol{\epsilon}$ & $\boldsymbol{\epsilon}$ \\
\hline Trigeneration plant & 20.2 & $2,270,000$ & 112,365 \\
Replacing fixtures with insulated glasses & 1 & 28,350 & 28,350 \\
Insertion of PV panels & 27.3 & 730,000 & 26,767 \\
Roof insulation & 3.4 & 71,775 & 21,195 \\
Replacing fixtures with low-e glasses & 57.1 & 494,646 & 8663 \\
Floor insulation & 7.6 & 37,950 & 5013 \\
Thermostatic valves & 30.7 & 65,380 & 2130 \\
Thermal solar collectors & 41 & 75,099 & 1833 \\
Geothermal plant & 51 & 87,000 & 1706 \\
\hline
\end{tabular}

Cost-benefit results highlight that a trigeneration plant installation is the intervention with higher cost for improving $E P_{\mathrm{gl}}$ of $1 \%$; replacing fixtures with insulated glasses an $\mathrm{PV}$ panels installation have a similar cost-benefit ratio; the same could be said for geothermal plant and thermal solar collectors, that are the intervention characterized by lower economic costs for improving $E P_{\mathrm{gl}}$ of $1 \%$.

\section{Conclusions}

The research analysed energy efficiency improvements and economic costs for some retrofitting interventions comparing results obtained in four public buildings located in the same geographical area. Only feasible interventions have been considered, according with each building's characteristics and local constraints. For example, it was not possible to analyse data coming from insulation of building facades, since it was not allowed in any of the considered buildings.

The obtained results do not claim to objectively demonstrate that a single intervention could have a better cost-benefit ratio in every building or every context, but only to give some indications about cost-benefit data obtained in four case studies that could be used by public administrations 
for preliminary analysis aimed to select specific interventions for reduction energy consumptions in public buildings trying to optimize cost- benefit ratio.

Indeed, the research gives useful inputs for decision makers and public administrations which have to select retrofitting interventions for improving energy performance of a specific public building, starting often with a limited budget. In particular, after selecting retrofitting interventions that could be made in compliance with the regulatory framework and the territorial context of the considered building, a further selection could be done comparing energy efficiency improvement and economic costs of each intervention.

Finally, since all the results have been obtained considering Italian parameters for economic costs of each intervention, the next steps of the research could include a comparison with data coming from other EU countries; in addition, an assessment of the actual reduction of energy consumptions after the interventions could be completed, allowing for an assessment of economic savings and payback time of each intervention.

Acknowledgments: The authors would like to thank all the students that collaborated in the data gathered in each one of the four analyzed buildings.

Author Contributions: All authors contributed equally in the writing of this paper. All authors have read and approved the final manuscript.

Conflicts of Interest: The authors declare no conflict of interest. The founding sponsors had no role in the design of the study; in the collection, analyses, or interpretation of data; in the writing of the manuscript, and in the decision to publish the results.

\section{Abbreviations}

$\begin{array}{ll}\text { APE } & \text { Energy Performance of Buildings } \\ \text { ASI } & \text { Italian Space Agency } \\ \text { BERC } & \text { Building Energy Regulation Codes } \\ \text { CHP } & \text { Combined heat and power } \\ \text { EPBD } & \text { Energy Performance of Buildings Directive } \\ \text { EPC } & \text { Energy Performance Certificate } \\ E P_{\mathrm{gl}} & \text { Global energy performance index }\left(\mathrm{kWh} /\left(\mathrm{m}^{2} \cdot \text { year }\right)\right) \\ E P_{\mathrm{H}} & \text { Energy performance index in the heating seasons }\left(\mathrm{kWh} /\left(\mathrm{m}^{2} \cdot \text { year }\right)\right) \\ E P_{\mathrm{W}} & \text { Energy performance index for domestic hot water production }\left(\mathrm{kWh} /\left(\mathrm{m}^{2} \cdot \text { year }\right)\right) \\ \text { EU } & \text { European Union } \\ \text { GHG } & \text { Greenhouse gas } \\ \text { GIS } & \text { Geographic information system } \\ \text { HVAC } & \text { Heating, ventilating and air conditioning } \\ \text { LCC } & \text { Life cycle cost } \\ \text { MiSE } & \text { Italian Ministry of Economic Development } \\ \text { PVD } & \text { Physical vapor deposition } \\ \text { RES } & \text { Renewable energy sources }\end{array}$

\section{References}

1. Viholainen, J.; Luoranen, M.; Väisänen, S.; Horttanainen, M.; Soukka, R. Regional level approach for increasing energy efficiency. Appl. Energy 2016, 163, 295-303. [CrossRef]

2. Shen, L.; He, B.; Jiao, L.; Song, X.; Zhang, X. Research on the development of main policy instruments for improving building energy-efficiency. J. Clean. Prod. 2016, 112, 1789-1803. [CrossRef]

3. Mattoni, B.; Gugliermetti, F.; Bisegna, F. A multilevel method to assess and design the renovation and integration of Smart Cities. Sustain. Cities Soc. 2015, 15, 105-119. [CrossRef]

4. Mattoni, B.; Pagliaro, F.; Gugliermetti, L.; Bisegna, F.; Cellucci, L. A Territorial Based Strategy for the Distribution of Sensor Networks in Smart Cities. In Proceedings of the IEEE 15th International Conference on Environment and Electrical Engineering, Rome, Italy, 10-13 June 2015; pp. 653-658.

5. Salvalai, G.; Masera, G.; Sesana, M.M. Italian local codes for energy efficiency of buildings: Theoretical definition and experimental application to a residential case study. Renew. Sustain. Energy Rev. 2015, 42, 1245-1259. [CrossRef] 
6. Tan, B.; Yavuz, Y.; Otay, E.N.; Çamlibel, E. Optimal selection of energy efficiency measures for energy sustainability of existing buildings. Comput. Oper. Res. 2016, 66, 258-271. [CrossRef]

7. Belpoti, V.; Bizzarri, G. A parametric method to assess the energy performance of the social housing stock and simulate suitable retrofit scenarios: An Italian case study. Energy Build. 2015, 96, 261-271. [CrossRef]

8. Carbonari, A.; Fioretti, R.; Lemma, M.; Principi, P. Managing Energy Retrofit of Acute Hospitals and Community Clinics through EPC Contracting: The MARTE project. Energy Procedia 2015, 78, 1033-1038. [CrossRef]

9. De Santoli, L.; Di Matteo, U. Building Energy and Environment Performance System (BEEPS): A programme for building energy certification in Italy. Build. Serv. Eng. Res. Technol. 2003, 24, 61-68. [CrossRef]

10. Monaco, A.; Di Matteo, U. Life cycle analysis and cost of a molten carbonate fuel cell prototype. Int. J. Hydrog. Energy 2011, 36, 8103-8111. [CrossRef]

11. Aste, N.; Caputo, P.; Buzzetti, M.; Fattore, M. Energy efficiency in buildings: What drives the investments? The case of Lombardy Region. Sustain. Cities Soc. 2016, 20, 27-37. [CrossRef]

12. Söderqvist, T.; Brinkhoff, P.; Norberg, T.; Back, P.-E.; Norrman, J. Cost-benefit analysis as a part of sustainability assessment of remediation alternatives for contaminated land. J. Environ. Manag. 2015, 157, 267-278. [CrossRef] [PubMed]

13. De Boeck, L.; Verbeke, S.; Audenaert, A.; De Mesmaeker, L. Improving the energy performance of residential buildings: A literature review. Renew. Sustain. Energy Rev. 2015, 52, 960-975. [CrossRef]

14. Nastasi, B. Renewable hydrogen potential for low-carbon retrofit of the building stocks. Energy Procedia 2015, 82, 944-949. [CrossRef]

15. Wang, Q.; Holmberg, S. A methodology to assess energy-demand savings and cost effectiveness of retrofitting in existing Swedish residential buildings. Sustain. Cities Soc. 2015, 14, 254-266. [CrossRef]

16. Paiho, S.; Abdurafikov, R.; Hoang, H. Cost analyses of energy-efficient renovations of a Moscow residential district. Sustain. Cities Soc. 2015, 14, 5-15. [CrossRef]

17. Şahina, C.D.; Arsanb, Z.D.; Tunçokuc, S.S.; Broströmd, T.; Akkurt, G.G. A transdisciplinary approach on the energy efficient retrofitting of a historic building in the Aegean Region of Turkey. Energy Build. 2015, 96, 128-139. [CrossRef]

18. Camprubí, L.; Malmusi, D.; Mehdipanah, R.; Palència, L.; Molnar, A.; Muntaner, C.; Borrell, C. Façade insulation retrofitting policy implementation process and its effects on health equity determinants: A realist review. Energy Policy 2016, 91, 304-314. [CrossRef]

19. Cumo, F.; Astiaso Garcia, D.; Calcagnini, L.; Rosa, F.; Sferra, A.S. Urban policies and sustainable energy management. Sustain. Cities Soc. 2012, 4, 29-34. [CrossRef]

20. De Santoli, L.; Albo, A.; Astiaso Garcia, D.; Bruschi, D.; Cumo, F. A preliminary energy and environmental assessment of a micro wind turbine prototype in natural protected areas. Sustain. Energy Technol. Assess. 2014, 8, 42-56. [CrossRef]

21. Astiaso Garcia, D.; Sangiorgio, S.; Rosa, F. Estimating the potential biomasses Energy source of forest and agricultural residues in the Cinque Terre Italian National Park. Energy Procedia 2015, 82, 674-680. [CrossRef]

22. Astiaso Garcia, D.; Cumo, F.; Pennacchia, E.; Sforzini, V. A sustainable requalification of bracciano lake waterfront in trevignano Romano. Int. J. Sustain. Dev. Plan. 2015, 10, 155-164. [CrossRef]

23. Cumo, F.; Astiaso Garcia, D.; Stefanini, V.; Tiberi, M. Technologies and strategies to design sustainable tourist accommodations in areas of high environmental value not connected to the electricity grid. Int. J. Sustain. Dev. Plan. 2015, 10, 20-28. [CrossRef]

24. Astiaso Garcia, D.; Cumo, F.; Giustini, F.; Pennacchia, E.; Fogheri, A.M. Eco-architecture and sustainable mobility: An integrated approach in Ladispoli town. WIT Trans. Built Environ. 2014, 142, 59-68.

25. Astiaso Garcia, D.; Cumo, F.; Sforzini, V.; Albo, A. Eco friendly service buildings for sustainable tourism and environmental awareness in protected areas. WIT Trans. Ecol. Environ. 2012, 161, 323-330.

26. Garcia, D.A.; Di Matteo, U.; Cumo, F. Selecting eco-friendly thermal systems for the "Vittoriale Degli Italiani" historic museum building. Sustainability 2015, 7, 12615-12633. [CrossRef]

27. Carbonara, E.; Tiberi, M.; Astiaso Garcia, D. Analysis of energy performance improvements in Italian residential buildings. Energy Procedia 2015, 82, 855-862. [CrossRef]

28. Astiaso Garcia, D.; Cinquepalmi, F.; Cumo, F. Air quality in Italian small harbours: A proposed assessment methodology. Rend. Lincei 2013, 24, 309-318. [CrossRef] 
29. Astiaso Garcia, D.; Bruschi, D.; Cinquepalmi, F.; Cumo, F. An estimation of urban fragmentation of natural habitats: Case studies of the 24 Italian National Parks. Chem. Eng. Trans. 2013, 32, 49-54.

30. Bruschi, D.; Astiaso Garcia, D.; Gugliermetti, F.; Cumo, F. Characterizing the fragmentation level of Italian's National Parks due to transportation infrastructures. Transp. Res. D 2015, 36, 18-28. [CrossRef]

31. Astiaso Garcia, D.; Cumo, F.; Gugliermetti, F.; Rosa, F. Hazardous and Noxious Substances (HNS) risk assessment along the Italian Coastline. Chem. Eng. Trans. 2013, 32, 115-120.

32. Sdringola, P.; Proietti, S.; Desideri, U.; Giombini, G. Thermo-fluid dynamic modeling and simulation of a bioclimatic solar greenhouse with self-cleaning and photovoltaic glasses. Energy Build. 2014, 68, 183-195. [CrossRef]

33. Gabay, H.; Meir, I.A.; Schwartz, M.; Werzberger, E. Cost-benefit analysis of green buildings: An Israeli office buildings case study. Energy Build. 2014, 76, 558-564. [CrossRef]

34. Monetti, V.; Fabrizio, E.; Filippi, M. Impact of low investment strategies for space heating control: Application of thermostatic radiators valves to an old residential building. Energy Build. 2015, 95, 202-210. [CrossRef]

35. Bulut, M.B.; Odlare, M.; Stigson, P.; Wallin, F.; Vassileva, I. Buildings in the future energy system-Perspectives of the Swedish energy and buildings sectors on current energy challenges. Energy Build. 2015, 107, 254-263. [CrossRef]

36. Lo Basso, G.; de Santoli, L.; Albo, A.; Nastasi, B. $\mathrm{H}_{2} \mathrm{NG}$ (hydrogen-natural gas mixtures) effects on energy performances of a condensing micro-CHP (combined heat and power) for residential applications: An expeditious assessment of water condensation and experimental analysis. Energy 2015, 84, 397-418. [CrossRef]

37. De Santoli, L.; Mancini, F.; Nastasi, B.; Piergrossi, V. Building integrated bioenergy production (BIBP): Economic sustainability analysis of Bari airport CHP (combined heat and power) upgrade fueled with bioenergy from short chain. Renew. Energy 2015, 81, 499-508. [CrossRef]

38. Nastasi, B.; de Santoli, L.; Albo, A.; Bruschi, D.; Lo Basso, G. RES (Renewable Energy Sources) Availability Assessments for Eco-fuels Production at Local Scale: Carbon Avoidance Costs Associated to a Hybrid Biomass $/ \mathrm{H}_{2}$ NG-based Energy Scenario. Energy Procedia 2015, 81, 1069-1076. [CrossRef]

(C) 2016 by the authors; licensee MDPI, Basel, Switzerland. This article is an open access article distributed under the terms and conditions of the Creative Commons Attribution (CC-BY) license (http://creativecommons.org/licenses/by/4.0/). 